\title{
Pengembangan Multimedia Interaktif Berbasis Kebudayaan Lokal pada Tema Indahnya Kebersamaan untuk Siswa Kelas IV
}

\author{
Sitti Aliffatul Hasanah ${ }^{1}$, Anang Santoso ${ }^{2}$, Furaidah ${ }^{3}$ \\ ${ }^{1}$ Pendidikan Dasar-Universitas Negeri Malang \\ ${ }^{2}$ Pendidikan Bahasa Indonesia-Universitas Negeri Malang \\ ${ }^{3}$ Pendidikan Bahasa Inggris-Universitas Negeri Malang
}

\begin{tabular}{l}
\hline \hline INFO ARTIKEL \\
\hline Riwayat Artikel: \\
Diterima: $19-12-2019$ \\
Disetujui: $19-10-2020$ \\
\hline
\end{tabular}

\section{Kata kunci:}

interactive multimedia;

local culture;

thematic learning;

multimedia interaktif;

kebudayaan lokal;

pembelajaran tematik

\begin{abstract}
ABSTRAK
Abstract: This research aims to produce interactive multimedia based on local culture that is feasible in terms of validity, practicality, attractiveness, and effectivity. The development model used was the Lee \& Owens model, consists of five steps: analysis, design, development, implementation, evaluation. The validator stated that interactive multimedia was very valid with a score of $92.9 \%$. Field test results showed that practicality of the product reached $94.5 \%$, and level of attractiveness reached $95.9 \%$. The results of the cognitive domain t-test were 8,746>1,671, the affective domain was $6,028>1,671$, and the psychomotor domain was $3,705>1,671$. Those three analysis points out that $\mathrm{t}$-empirical $>\mathrm{t}$-table. It was concluded that interactive mulitmedia was valid, practical, attractive and effective.
\end{abstract}

\begin{abstract}
Abstrak: Penelitian ini bertujuan menghasilkan multimedia interaktif berbasis kebudayaan lokal yang valid, praktis, menarik, dan efektif. Model pengembangan menggunakan model Lee \& Owens, terdiri dari lima tahap, yaitu analisis, desain, pengembangan, implementasi, dan evaluasi. Validator menyatakan multimedia interaktif yang dikembangkan telah sangat valid dengan perolehan skor 92,9\%. Hasil uji lapangan menunjukkan tingkat kepraktisan produk mencapai 94,5\%, dan tingkat kemenarikan mencapai $95,9 \%$. Hasil perhitungan uji- $t$ ranah kognitif adalah $8,746>1,671$, ranah afektif adalah $6,028>1,671$, dan ranah psikomotor adalah $3,705>1,671$. Ketiga analisis uji-t menunjukkan $t$-empirik $>t$-tabel. Disimpulkan bahwa multimedia interaktif telah valid, praktis, menarik, dan efektif.
\end{abstract}

\section{Alamat Korespondensi:}

Sitti Aliffatul Hasanah

Pendidikan Dasar

Universitas Negeri Malang

Jalan Semarang 5 Malang

E-mail: sittialiffatul@gmail.com
Pelaksanaan proses pembelajaran adalah inti dari pendidikan di sekolah dan berperan penting dalam menentukan tercapai tidaknya sebuah tujuan pembelajaran. Adapun keberhasilan tujuan pembelajaran dapat ditentukan dengan melihat hasil belajar seorang siswa, atau ada tidaknya perubahan dalam diri siswa (Siagian, 2015). Namun, hasil belajar atau tujuan tersebut tidak dapat tercapai apabila dalam proses penyampaian pembelajaran tidak tepat (Arsyad, 2016). Oleh karena itu, ada beberapa komponen pembelajaran yang harus diperhatikan saat proses pembelajaran, salah satunya adalah media pembelajaran (Rumihat, 2011). Heinich (Susanto, 2016) menyatakan bahwa media atau medium adalah sebuah perantara untuk menyampaikan informasi antara sumber dan penerima, dalam hal ini guru dan siswa. Proses pembelajaran sejatinya adalah proses komunikasi (pengkodean) baik secara verbal maupun nonverbal (encoding) yang kemudian ditafsirkan dalam bentuk simbol-simbol tertentu oleh siswa di dalam pikirannya (decoding) (Daryanto, 2015). Dalam penafsiran tersebut, ada kalanya siswa berhasil atau gagal. Kegagalan dapat terjadi apabila siswa kurang dapat memahami dengan baik informasi yang diterimanya. Media pembelajaran dapat membantu penyampaian isi pembelajaran supaya tidak sepenuhnya verbalisme sehingga dapat mengurangi terjadinya gangguan yang menjadi penghambat komunikasi (Daryanto, 2015).

Media pembelajaran juga dapat meningkatkan pengalaman belajar siswa. Proses belajar yang baik adalah pembentukan pengetahuan yang didapatkan siswa berdasarkan pengalamannya sendiri dalam berinteraksi dengan lingkungannya (Slameto, 2015). Pada kenyataannya, pembelajaran di sekolah tidak selalu mampu menyajikan pengalaman langsung bagi siswa. Misalnya untuk mengenalkan berbagai jenis pakaian adat dari seluruh nusantara. Hal ini akan membutuhkan biaya, waktu dan ruang yang tidak sedikit. Penggunaan media pembelajaran menjadi solusi untuk mengatasi berbagai kendala yang dialami guru, mulai dari 
biaya, keterbatasan waktu, dan ruang sekalipun (Sanjaya, 2010). Berdasarkan kerucut pengalaman Dale (Sanjaya, 2010), siswa yang terlibat aktif dalam kegiatan berdiskusi akan meningkat pengalaman belajarnya menjadi 70\%. Berdasarkan kerucut pengalaman Dale, kita dapat mengetahui bahwa dengan menggunakan media tertentu akan dapat meningkatkan pengalaman yang diperoleh siswa. Hasil studi yang serupa dikatakan pula oleh (Serva \& Fuller, 2004) penggunaan media pembelajaran secara efektif akan dapat meningkatkan pengalaman belajar. Misalnya, seperti siswa mengamati sebuah video pembelajaran, siswa akan dapat merasakan keterlibatan langsung dibandingkan menggunakan satu metode saja, misalnya metode ceramah.

Penggunaan media sangat menunjang proses pembelajaran di kelas, terutama di tingkat sekolah dasar. Media mampu membantu guru menyajikan pembelajaran yang sesuai dengan perkembangan kognitif anak. Berdasarkan teori perkembangan kognitif Jean Piaget (Papalia, 2015), perkembangan kognitif siswa SD berada pada tahap oprasional konkret. Pada tahap ini, seseorang dapat membentuk pengetahuan dan ide berdasarkan kejadian logis atau objek konkret yang ada di sekitarnya (Lindsay, 2011). Objek konkret adalah objek yang dapat diindrawi oleh siswa, baik itu indra penglihat, indra peraba, indra pendengar, pengecap maupun pencium. Dalam hal ini, objek konkret tersebut terwujud dalam bentuk sebuah media. Penggunaan media sebagai objek konkret di kelas, akan meningkatkan keefektifan proses penyampaian materi. Contohnya, penggunaan media audio menyebabkan perbedaan dalam pencapaian siswa dalam hal kemampuan melafalkan bahasa Inggris yang diajarkan menggunakan media audio dengan mereka yang diajar menggunakan metode ekspositori. Media dapat meningkatkan kinerja siswa dalam berbagai kegiatan pembelajaran termasuk kemampuan untuk membaca dan menulis (Ngussa \& Chiza, 2017). Oleh sebab itu, media pembelajaran adalah sebuah bagian integral dari sebuah pengajaran (Wamalwa \& Wamalwa, 2014).

Karakteristik siswa lainnya adalah, mereka memiliki rentang perhatian yang sangat terbatas, kecuali pada kegiatankegiatan yang dirasa sangat menarik. Rentang perhatian adalah jumlah waktu konsentrasi yang dapat dilakukan seseorang untuk mengerjakan suatu tugas tanpa terganggu (Bradbury, 2016; Levin \& Bernier, 2011). Pada anak pada usia operasional konkret yaitu 7-11 tahun, rentang perhatian maksimal yang dapat dilakukan memanglah hanya dibawah 15 menit saja (Alim, 2009; Mayer, 2003). Contohnya, anak dapat bermain game sampai berjam-jam karena anak senang dan penasaran. Berdasarkan fakta tersebut, untuk mempanjang rentang perhatian siswa, proses pembelajaran hendaklah membuat anak merasa senang dan penasaran (Harmer, 2007). Rasa senang dan penasaran dapat terbentuk salah satunya adalah dari penggunaan media pembelajaran yang baik (Naz \& Akbar, 2010). Media juga dapat membuat siswa merasa senang terlibat dalam pembelajaran, sehingga dapat memotivasi mereka untuk mengulang kembali pembelajaran yang dialaminya (Manjale \& Abel, 2017). Berdasarkan berbagai pendapat yang sudah disebutkan, dapat disimpulkan bahwa upaya peningkatan tingkat konsentrasi atau rentang perhatian siswa dapat dilakukan dengan menggunakan berbagai variasi media dalam kegiatan pembelajaran.

Karakteristik siswa sekolah dasar lainnya yang juga perlu diperhatikan adalah ketidakmampuan mereka untuk diam dalam waktu yang lama. Orang dewasa mungkin dapat duduk diam hingga berjam-jam, namun anak sekolah dasar hanya mampu duduk tenang dengan durasi paling lama adalah 30 menit (Alim, 2009). Tidak heran jika anak sekolah dasar sangat suka bergerak dan tidak bisa diam terlalu lama karena sesungguhnya pemahaman mereka tidak hanya dibentuk dari proses mendengarkan, tetapi juga sangat ditentukan dari apa yang dilihat, disentuh, dan kegiatan interaksi (Harmer, 2007). Kegiatan bergerak aktif akan merangsang lebih banyak sel otak bekerja dan memperlancar sirkulasi pembuluh dasar di otak (Carlson et al., 2015). Oleh karena itu, penggunaan media pembelajaran sangat relevan dengan siswa sekolah dasar karena dapat memfasilitasi karakteristik siswa yang suka bergerak dan tidak bisa diam (Sanjaya, 2010). Media pembelajaran mampu membuat anak terlibat aktif dalam kegiatan belajar dan berinterasksi dengan teman lainnya.

Pada kenyataannya, pentingnya penggunaan media pembelajaran ternyata belum dipahami sepenuhnya oleh para pendidik. Guru-guru cenderung masih menggunakan bahan ajar yang monoton atau tinggal pakai saja (Zuriah, Sunaryo, \& Yusuf, 2016). Fenomena ini sesuai dengan studi pendahuluan yang dilakukan, yaitu observasi proses pembelajaran di kelas IV. Ditemukan bahwa guru menggunakan buku guru dan siswa sebagai satu-satunya sumber belajar sekaligus media pembelajaran. Tidak ada media pendukung lainnya yang digunakan untuk menyampaikan materi pembelajaran, padahal sekolah memiliki laboratorium komputer dan LCD. Keterbatasan media ini mengakibatkan siswa kurang terlibat dalam pembelajaran karena siswa dibatasi hanya untuk mendengarkan dan mengamati penyampaian materi oleh guru, serta menyelesaikan tugas sesuai instruksi guru. Salah satu faktor guru jarang menyiapkan media pembelajaran lainnya karena keterbatasan waktu, biaya, dan keahlian (Alwi, 2017). Fasilitas LCD yang disediakan sekolah pun masih sangat jarang dimanfaatkan karena dirasa cukup merepotkan untuk menyiapkan alat dan bahannya. Berdasarkan hal tersebut, tidak heran jika ternyata nilai belajar siswa juga masih rendah. Ada sekitar 43\% siswa yang masih mendapat nilai dibawah KKM. Besar kemungkinan bahwa keterbatasan media dalam pembelajaran menjadi salah satu penyebabnya.

Wawancara yang dilakukan kepada beberapa, menyimpulkan bahwa pembelajaran di kelas kurang mengasyikkan. Mereka lebih suka pembelajaran kesenian karena mereka dapat melakukan banyak hal, seperti mewarna, menggambar, dan menggunting. Hal ini mengindikasikan bahwa siswa menyukai pembalajaran yang membuat mereka melakukan berbagai kegiatan secara aktif. Ketika siswa ditanya mengenai materi yang disampaikan oleh guru, sebagian siswa kesulitan untuk menjawab dan bahkan ada tidak dapat menjawab sama sekali. Hal ini mungkin diakibatkan karena sebagian dari mereka tidak memberikan perhatian atau konsentrasi yang cukup saat materi pelajaran disampaikan oleh guru. Pembelajaran yang monoton dan tidak menggunakan media pembelajaran akan cenderung membuat siswa merasa tidak tertarik dan bosan sehingga tujuan pembelajaran tidak dapat dicapai secara maksimal (Zuriah et al., 2016). 
Berdasarkan analisis permasalahan yang didapatkan dari hasil observasi dan wawancara, maka penting untuk dicari solusi yang tepat untuk mengatasinya. Salah satu alternatif solusinya adalah penggunaan variasi media pembelajaran yang dipadukan dengan teknologi (Mikre, 2011). Kemajuan teknologi ini telah merangsang terciptanya berbagai pendekatan yang lebih menarik dan efektif dalam konteks belajar-mengajar (Fui-Theng LEOW \& Assoc. Prof. Dr Mai NEO, 2014). Salah satunya dampaknya yang mungkin sangat menarik dalam dunia pendidikan adalah teknologi multimedia (Nusir, Alsmadi, AlKabi, \& Shardqah, 2011). Multimedia memiliki kemampuan untuk membuat lingkungan pelajar menjadi lebih berkualitas karena memungkinkan siswa untuk memegang kendali dari proses belajar mereka sendiri. Lingkungan belajar menjadi lebih efektif karena dapat memfasilitasi berbagai jenis pelajar (Ilhan \& Oruç, 2016).

Didukung dengan tersedianya laboratorium konputer di sekolah yang seharusnya dapat dimanfaatkan secara maksimal oleh guru-guru. Laboratorium komputer berpotensi menjadi sumber daya yang dapat digunakan oleh guru untuk banyak hal (Gunawardhana \& Palaniappan, 2016), karena penggunaan teknologi komputer dalam pelaksanaan pendidikan terbukti dapat memotivasi siswa dan meningkatkan kemampuan akademik mereka (Komba \& David, 2015). Metode pembelajaran yang canggih dan komputerisasi, lebih mudah digunakan, dan lebih menarik bagi anak-anak dapat diterapkan sebagai alat bantu untuk kegiatan belajar mengajar (Kurniawan, 2018). Kemenarikan metode maupun alat yang digunakan dalam pembelajaran dapat meningkatkan daya konsentrasi siswa sekolah dasar.

Ada beberapa alasan dipilihnya multimedia interaktif dalam penelitian ini. Pertama, sesuai dengan perkembangan kognitif siswa yang membutuhkan benda-benda konkret untuk membantu pekembangan kognitifnya. Untuk mendukung perkembangan kognitifnya supaya dapat belajar secara maksimal, siswa harus menggunakan keseluruhan indrawinya dalam berinteraksi dengan benda konkret di sekitarnya. Anak-anak belajar terbaik melalui indera dominan mereka, yaitu melihat, mendengar dan menyentuh (Wey, Lin, Chen, Application, \& Chen, 2014). Multimedia interaktif dapat melibatkan ketiga indera ini secara bersamaan melalui berbagai representasi visual, suara dan kapasitas untuk menyentuh dan berinteraksi dengan multimedia interaktif. Melalui multimedia interaktif, siswa akan terbantu untuk memvisualisasikan konsep-konsep yang abstrak melalui gambar, audio, video, animasi, dan interaksi yang bersifat langsung dan nyata (Osman \& Lee, 2014).

Kedua, multimedia interaktif terbukti mampu menambah rentang perhatian siswa. Multimedia dapat mendorong siswa untuk memperhatikan lebih lama daripada biasanya (Ian Hall \& S Higgins, 2005) karena berbagai elemen, yakni gambar, video, suara, dan animasi dalam multimedia dapat membantu meningkatkan keterlibatan, motivasi dan rentang perhatian siswa (Kirkorian, Wartella, \& Anderson, 2008). Multimedia interaktif memiliki semua komponen yang dapat menarik perhatian siswa, mulai dari gambar yang menarik, animasi yang menarik, video yang tidak membosankan, dan interactive link yang seakan-akan memberikan tanggapan pada setiap gerak-gerik siswa.

Selain didukung oleh teori media pembelajaran dan multimedia interaktif, berbagai penelitian terdahulu juga telah membuktikan keefektifan multimedia pembelajaran untuk meningkatkan hasil belajar siswa (Arkün \& Akkoyunlu, 2008; Mai, Yeen-ju, \& Ludin, 2016; Prasetya, Kuswandi, \& Akbar, 2018). Perbedaan penelitian ini dengan penelitian sebelumnya, adalah multimedia interaktif ini akan berupaya untuk pengintegrasian kebudayaan daerah tempat siswa tinggal, supaya siswa mengetahui keindahan apa yang dimiliki oleh daerahnya dan bangga terhadap budaya daerah sendiri. Pembelajaran yang menyisipkan kebudayaan lokal juga akan lebih mudah dipahami siswa (Harsiwi, Yuliati, \& Suardana, 2017; Khuriyah, Utaya, \& Sapto, 2017), karena materi tersebut bersasal dari lingkungan siswa atau bersifat pembelajaran kontekstual (Nilasari, Adrian, \& Susanto, 2018). Selain itu, perbedaan lainnya juga terletak di pengujian keefektifan media yang dikembangkan. Dalam penelelitian ini, akan digunakan uji keefektifan dengan metode quasy experiment, sehingga hasil keefektifan yang didapatkan jauh lebih valid karena ada kelas pembanding sebagai kelas kontrol.

\section{METODE}

Penelitian ini adalah jenis penelitian dan pengembangakan yang bertujuan untuk menghasilkan produk multimedia interaktif untuk siswa sekolah dasar. Model penelitian yang digunakan adalah Lee \& Owens yang terdiri atas lima langkah pengembangan, seperti gambar 1 .

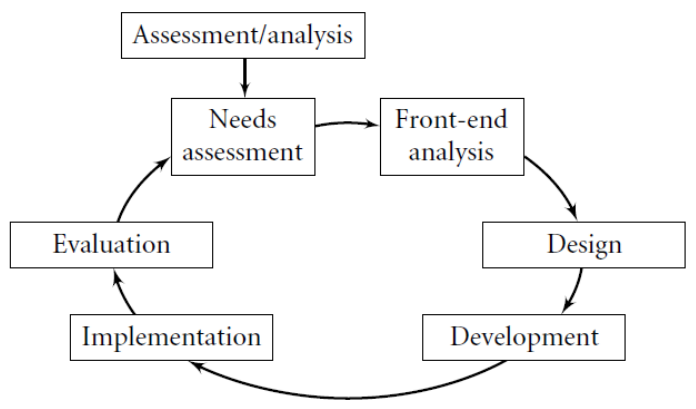

Gambar 1. Proses Pengembangan Pembelajaran Multimedia 
Tahap pertama, yakni analisis kebutuhan adalah sebuah tahap yang berisi kegiatan mencari tahu dan menggali informasi mengenai ketidaksesuaian antara kondisi ideal dengan kenyataan di lapangan. Tujuannya adalah supaya multimedia interaktif yang dikembangkan dapat memenuhi kebutuhan yang di lapangan. Analisis kebutuhan dilakukan dengan melakukan studi pendahuluan, yakni dengan melakukan observasi dan/atau wawancara. Tahap kedua, yakni tahap desain. Hal yang dilakukan dalam tahap ini adalah membuat blueprint terkait media yang akan dikembangkan. Perlu dilakukan penyusunan jadwal, penentuan struktur materi dan tim proyek, dan spesifikasi media yang diinginkan. Tahap ketiga adalah tahap mengembangkan media yang telah dirancang. Blueprint yang sudah dibuat, dituangkan dalam program Adobe Flash CS3. Hasil dari tahap ketiga ini adalah berupa prototype multimedia interaktif yang sudah siap untuk divalidasi oleh ahli dan uji coba terbatas. Tahap keempat adalah implementasi. Pada tahapan ini, pihak-pihak yang terlibat antara lain adalah ahli materi, ahli media, guru, dan siswa. Produk divalidasi kepada ahli media dan ahli materi. Berdasarkan hasil validasi produk direvisi sesuai saran, komentar, tanggapan dan kritikan oleh ahli media dan ahli materi. Selanjutnya, produk diujicoba secara perorangan dan direvisi kemudian diujicoba ke lapangan. Tahap terakhir, yakni evaluasi dilakukan dengan menganalisis data yang sudah didapat pada tahap implementasi. Tahap ini digunakan untuk mengetahui ketercapaian tujuan dalam pengembangan yang dilakukan.

Uji coba produk dalam penelitian ini terdiri dari 2 bagian, yakni validasi ahli dan uji coba pengguna. Validasi ahli dilakukan oleh ahli media dan ahli materi. Validasi ini bertujuan untuk mengetahui tingkat kevalidan multimedia interaktif, apakah sudah sesuai dengan teori yang benar dan pengalaman para ahli. Selanjutnya, uji coba pengguna yang terdiri dari dua tahap sebagai berikut. Pertama, uji coba terbatas. Produk yang telah direvisi sesuai masukan ahli, diterapkan secara terbatas di lapangan. Guru kelas IV dan beberapa siswa (heterogen) kelas IV dari MI At-Taqwa Bondowoso akan menggunakan multimedia interaktif ini dalam proses pembelajaran. Tujuannya adalah untuk mengetahui kelayakan awal produk yang dikembangkan, yakni meliputi aspek kepraktisan dan kemenarikan. Instrumen yang digunakan berupa angket pengguna bagi guru dan siswa. Kedua, uji coba lapangan. Uji coba lapangan ini dilakukan terbatas hanya di kelas IV MI At-Taqwa Bondowoso. Tujuan dilakukannya uji coba lapangan adalah untuk mengetahui tingkat kepraktisan, kemenarikan, dan tingkat keefektifan. Instrumen yang diguanakan untuk memperoleh data tersebut adalah angket, tes, dan lembar observasi. Dalam uji coba lapangan, digunakan metode quasi experimental desain. Berikut desain penelitian untuk uji keefektifan multimedia interaktif disajikan pada gambar 2 .

\begin{tabular}{lll}
\hline $\mathbf{O}$ & $\mathbf{X}$ & $\mathbf{P}$ \\
\hline $\mathbf{O}$ & - & $\mathbf{P}$ \\
\hline
\end{tabular}

\section{Gambar 2. Desain Penelitian Non Equivalent Control Grup Design}

\section{Keterangan:}

$\begin{array}{ll}\mathrm{O} & \text { : Pretest } \\ \mathrm{P} & \text { : Posttest } \\ \mathrm{X} & \text { : Perlakuan }\end{array}$

Populasi dalam penelitian ini adalah siswa kelas IV MI At-Taqwa Bondowoso, dan sampelnya adalah kelas IVE dan IVF. Penentuan sampel ini dilakukan melalui uji homogenitas menggunakan ANOVA untuk mengetahui apakah seluruh populasi homogen atau tidak. Berdasarkan hasil uji homogenitas, diperoleh bahwa keseluruhan popolasi adalah homogen. Oleh karena itu, penetuan sampel dilakukan dengan teknik random sampling yang diperoleh melalui undian. Kelas eksperimen akan diberikan perlakuan khusus (treatmen) yakni akan dibelajarkan menggunakan multimedia interaktif selama seminggu pembelajaran, sedangkan kelas kontrol tidak akan diberikan perluan khusus apapun. Kelas kontrol akan belajar sebagaimana guru mengajar biasanya (menggunakan media gambar seadanya). Setelah kedua kelas belajar selama seminggu, selanjutnya dilakukan tes untuk mengetahui perbedaan hasil belajar kedua kelas tersebut, baik dari segi kognitif, afektif, dan psikomotorik.

Terdapat dua jenis data yang akan dianalisis dalam penelitian ini, yakni data kualitatif dan kuantitatif. Data kualitatif adalah berupa masukan dan saran dari validator dan pengguna. Sedangkan data kuantitatif berupa perhitungan skor angket kevalidan, kepraktisan, kemenarikan dan uji t-test keefektifan. Data hasil validasi ahli dan angket pengguna dianalisis menggunakan rumus berikut.

$$
V=\frac{T s e}{T s h} \times 100 \%
$$

Keterangan:

$\mathrm{V} \quad=$ Validitas

Tse $\quad=$ Total skor empirik

TSh = Skor maksimal yang diharapkan (Akbar, 2016) 
Hasil perhitungan kemudian dikonsultasikan dengan tabel 1. Kriteria Kevalidan, Kepraktisan, dan Kemenarikan sebagai berikut.

\section{Tabel 1. Kriteria Kevalidan, Kepraktisan, dan Kemenarikan}

\begin{tabular}{ccll}
\hline No & Rentangan nilai & \multicolumn{1}{c}{ Kriteria Kevalidan, Kepraktisan, dan Kemenarikan } & Keterangan \\
\hline 1 & $81-100 \%$ & Sangat valid/sangat praktis/sangat menarik & dapat digunakan tanpa perbaikan \\
2 & $61-80 \%$ & Valid/praktis/menarik & dapat digunakan namun perlu perbaikan kecil \\
3 & $41-60 \%$ & Kurang valid/kurang praktis/kurang menarik & didak dapat digunakan \\
4 & $21-40 \%$ & Tidak valid/tidak praktis/tidak menarik & tidak dapat digunakan \\
5 & $0-20 \%$ & Sangat Tidak Valid/sangat tidak praktis/sangat tidak menarik & \\
\hline
\end{tabular}

Sumber: Modifikasi (Akbar, 2016)

Uji keefektifan dilakukan menggunakan uji $t$ menggunakan teknik analisis t-test Independent Sampling. Perhitungannya dapat dilakukan dengan menggunakan SPSS versi 17. Hasil analisis $t$-test kemudian dikonsultasikan dengan $t$ tabel dengan db 62. Jika nilai $t$-test lebih besar atau sama dengan $t$-tabel $(1,671)$, maka dapat disimpulkan bahwa multimedia interaktif yang dikembangkan adalah efektif.

\section{HASIL}

Hasil akhir penelitian dan pengembangan yang dilakukan adalah berupa multimedia interaaktif berbasis kebudayaan lokal Kabupaten Bondowoso pada tema indahnya kebersamaan subtema keberagaman budaya bangsaku yang diperuntukkan siswa kelas IV Sekolah Dasar. Multimedia ini dirancang untuk membantu siswa belajar dengan cara yang lebih menyenangkan. Multimedia ini mengembangkan materi untuk pembelajaran tematik di sekolah dasar, tepatnya pada tema indahnya kebersamaan subtema keberagaman budaya bangsaku, yang bermuatan PPKn, IPS, Bahasa Indonesia, IPA dan SBdP. Produk multimedia interaktif ini dikemas dalam bentuk $\mathrm{CD}$, dilengkapi buku petunjuk penggunaan untuk guru dan siswa, serta Rencana Pelaksanaan Pembelajaran (RPP).

\section{Tayangan Pembuka}

Pada tayangan pembuka ini, ditampilkan sebuah percakapan antara Siti dan Arif. Siti dan Arif bercakap-cakap mengenai tema dan subtema yang akan dipelajari, yakni tema indahnya kebersamaan, subtema keberagaman budaya bangsaku.. Tayangan pembuka pada bagian ini didukung dengan animasi berupa peta Indonesia dan tokoh berpakaian adat, sesuai dengan tema. Setelah tayangan pembuka selesai, siswa diajak berdoa bersama sesuai keyakinan masing-masing.

\section{Menu Utama}

Dalam menu ini, ditampilkan ikon-ikon yang mengarahkan pengguna pada halaman-halaman tertentu. Ada lima menu utama yang dapat dijelajahi oleh siswa, yaitu menu petunjuk penggunaan, tujuan pembelajaran, kegiatan pembelajaran, evaluasi pembelajaran dan profil pengembang. Halaman ini diberi background atau latar berupa peta Indonesia yang ditahan oleh kedua tangan. Latar ini menggambarkan tema Indahnya Kebersamaan, yaitu merangkul semua perbedaan yang ada di Indonesia dengan tangan terbuka.

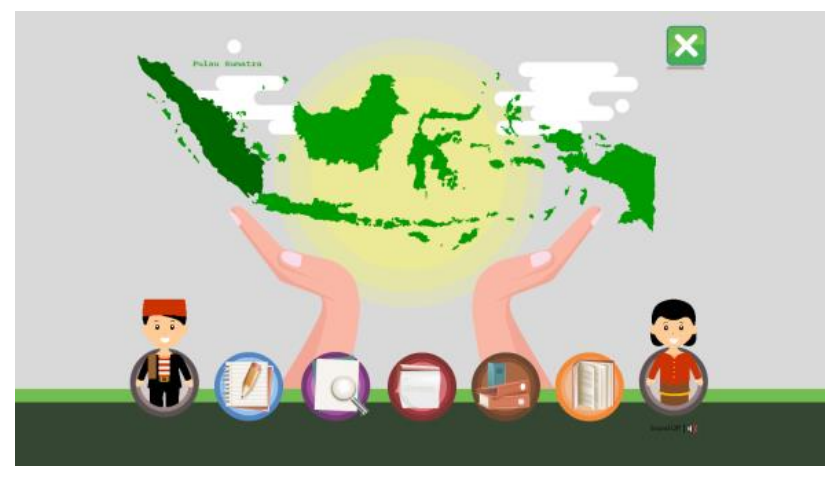

Gambar 3. Tampilan Menu Utama

\section{Menu Petunjuk Penggunaan}

Menu ini berisi keterangan dan tombol-tombol dalam multimedia interaktif. Jadi, guru dan siswa ataupun pengguna lainnya dianjurkan untuk membaca menu ini untuk pertama kali penggunaan supaya dapat lebih mudah mengoperasikan multimedia interaktif. 


\section{Menu Tujuan Pembelajaran}

Menu ini berisi tentang tujuan pembelajaran dari setiap kegiatan belajar. Ada lima pembelajaran, jadi ada lima submenu tujuan pembelajaran. Melalui menu ini, siswa dapat mengetahui tujuan apa yang hendak dicapai melalui kegiatan pembelajaran yang akan mereka lakukan.

\section{Menu Kegiatan Pembelajaran}

Menu kegiatan pembelajaran ini berisi lima submenu atau kegiatan pembelajaran. Siswa dituntun untuk memilih submenu pembelajaran sesuai jadwal belajar hari itu. Kelima kegiatan pembelajaran memiliki materi dan jenis kegiatan yang bervariasi, sesuai dengan tujuan pembelajaran masing-masing. Terdapat kegiatan memilah dan memilih, mencoba, menduga, mengamati video, menjawab pertanyaan, membaca bacaan, melakukan percobaan, menirukan gerakan tari, dan berbagai kegiatan lainnya. Berikut adalah beberapa tampilan dalam menu kegiatan pembelajaran dapat dilihat pada gambar 3.
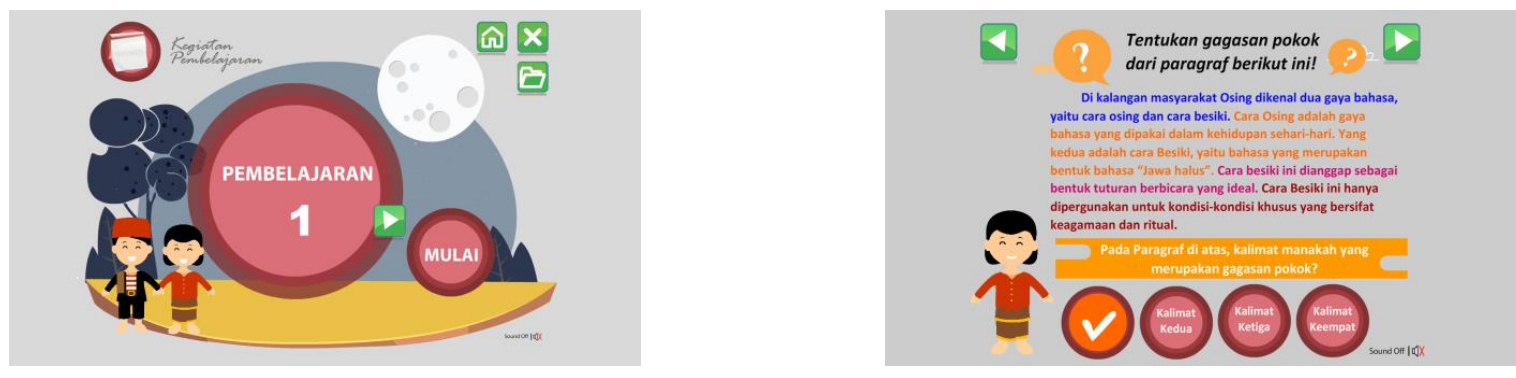

\section{Gambar 4. Tampilan Kegiatan Pembelajaran}

\section{Menu Evaluasi}

Menu evaluasi berisi masing-masing soal pilihan ganda dan uraian yang berkaitan dengan masing-masing pembelajaran yang telah dilakukan. Terdiri dari 10 soal pilihan ganda dan 5 soal uraian.

\section{Menu Profil Pengembang}

Menu terakhir dalam multimedia interaktif ini adalah profil pengembang. Menu isi berisi tentang biodata dari pengembang atau peneliti. Adapun informais yang tersedia antara lain adalah nama lengkap, nomer telepon, dan email.

Hasil perhitungan tingkat kevalidan berdasarkan penilaian para ahli terhadap multimedia interaktif yang dikembangkan, dapat dilihat pada tabel 2 .

Tabel 2. Rekapituliasi Hasil Validasi Para Ahli

\begin{tabular}{clc}
\hline No. & Validator & Persentase \\
\hline 1. & Ahli Media & $92,5 \%$ \\
2. & Ahli Materi & $93,3 \%$ \\
\hline & Rata-rata & $92,9 \%$
\end{tabular}

Berdasarkan hasil rekapitulasi tabel 2, didapatkan tingkat kevalidan multimedia interaktif yang dikembangkan adalah 92,9\%. Artinya, multimedia interaktif sangat valid dan layak digunakan. Setelah divalidasi oleh ahli media, selanjutnya adalah uji coba terbatas. Berikut disajikan perhitungan tingkat kepraktisan berdasarkan hasil angket pengguna saat uji coba terbatas dan uji coba lapangan pada tabel 3 .

Tabel 3. Rakapitulasi Hasil Angket Kepraktisan

\begin{tabular}{clc}
\hline No. & Pengguna & Persentase \\
\hline & Uji Coba Terbatas & \\
\hline 1. & Guru & $87,5 \%$ \\
2. & Siswa & $96 \%$ \\
\hline \multicolumn{2}{l}{ Uji Coba Lapangan } \\
\hline 1. & Guru & $95,8 \%$ \\
2. & Siswa & $96,9 \%$ \\
\hline & Rata-rata & $94,5 \%$ \\
\hline
\end{tabular}


Berdasarkan hasil rekapitulasi tabel 3, didapatkan tingkat kepraktisan multimedia interaktif yang dikembangkan adalah 94,5\%. Artinya, multimedia interaktif sangat praktis dan layak digunakan. Sementara itu, untuk hasil rekapitulasi tingkat kemenarikan disajikan pada tabel 4.

Tabel 4. Rakapitulasi Hasil Angket Kemenarikan

\begin{tabular}{clc}
\hline No. & \multicolumn{1}{c}{ Pengguna } & Persentase \\
\hline & Uji Coba Terbatas & \\
1. & Guru & $90 \%$ \\
2. & Siswa & $98,2 \%$ \\
& Uji Coba Lapangan & \\
1. & Guru & $97,5 \%$ \\
2. & Siswa & $98 \%$ \\
& Rata-rata & $95,9 \%$ \\
\hline
\end{tabular}

Berdasarkan hasil rekapitulasi tabel 4, didapatkan tingkat kemenarikan multimedia interaktif yang dikembangkan adalah 95,9\%. Artinya, multimedia interaktif sangat menarik dan layak digunakan. Selanjutnya, tingkat keefektifan multimedia interaktif diperhitungkan dengan cara membandingkat beda hasil pretest dan posttest kelas kontrol dan kelas eksperimen (sesuai masing-masing ranah hasil belajar). Tabel 5 berikut adalah hasil $t$-test ranah kognitif.

Tabel 5. Uji-t Hasil Belajar Ranah Kognitif

\begin{tabular}{llccc}
\hline & & \multicolumn{3}{c}{ Uji t untuk perbedaan rerata } \\
& & t & df & Sig. (2-tailed) \\
\hline \multirow{2}{*}{ Hasil Belajar } & Asumsi varian sama & 7,386 & 62 &, 000 \\
& Asumsi varian tidak sama & 7,387 & 61,797 &, 000 \\
\hline
\end{tabular}

Berdasarkan pehitungan uji t menggunakan program SPSS, diketahui diperoleh $t$ hitung sebesar 7,386. Selanjutnya, hasil $t$ hitung tersebut dikonultasikan pada tabel kritik t ( $t$-tabel) pada taraf sigifikansi 0,05 . Nilai $t$ tabel untuk taraf signifikansi 0,05 dengan db 62 adalah sebesar 1,671. Hal tersebut menujukkan bahwa nilai $t$ hitung lebih besar darapada $t$ tabel $(7,386>1,671)$. Berdasarkan perhitungan tersebut, disimpulkan bahwa produk multimedia interaktif yang dikembangkan efektif untuk meningkatkan hesil belajar siswa ranah kognitif. Untuk ranah afektif, disajikan pada tabel 6.

Tabel 6. Uji-t Hasil Belajar Ranah Afektif

\begin{tabular}{clccc}
\hline & & \multicolumn{3}{c}{ Uji t untuk perbedaan rerata } \\
& & t & df & Sig. (2-tailed) \\
\hline \multirow{2}{*}{ Hasil Belajar } & Asumsi varian sama & 4,643 & 62 &, 000 \\
& Asumsi varian tidak sama & 4,691 & 57,954 &, 000 \\
\hline
\end{tabular}

Berdasarkan pehitungan uji t menggunakan program SPSS, diketahui diperoleh $t$ hitung sebesar 4,643. Hal tersebut menujukkan bahwa nilai $t$ hitung lebih besar darapada $t$ tabel $(4,643>1,671)$. Berdasarkan perhitungan tersebut, disimpulkan bahwa produk multimedia interaktif yang dikembangkan efektif untuk meningkatkan hesil belajar siswa ranah afektif. Berikut disajikan pula hasil uji t untuk ranah psikomotor pada tabel 7.

Tabel 7. Uji-t Hasil Belajar Ranah Psikomotor

\begin{tabular}{llccc}
\hline & & \multicolumn{3}{c}{ Uji t untuk perbedaan rerata } \\
& & t & df & Sig. (2-tailed) \\
\hline \multirow{2}{*}{ Hasil Belajar } & Asumsi varian sama & 2,289 & 62 &, 000 \\
& Asumsi varian tidak sama & 2,313 & 58,093 &, 000 \\
\hline
\end{tabular}

Berdasarkan pehitungan uji t menggunakan program SPSS, diketahui diperoleh $t$ hitung sebesar 2,289. Hal tersebut menujukkan bahwa nilai $t$ hitung lebih besar darapada $t$ tabel $(2,289>1,671)$. Berdasarkan perhitungan tersebut, disimpulkan bahwa produk multimedia interaktif yang dikembangkan efektif untuk meningkatkan hesil belajar siswa ranah psikomotor.

\section{PEMBAHASAN}

Keberhasilan multimadia interaktif yang dikembangkan disebabkan karena multimedia interaktif dikembangkan sesuai dengan siswa dan bertujuan memenuhi kebutuhan dan karakteristik siswa sekolah dasar. Ditinjau dari teori perkembangan kognitif Jean Piaget (Papalia, 2015), perkembangan kognitif anak sekolah dasar sedang berada pada tahap oprasional konkret. Untuk mendukung perkembangan kognitifnya supaya dapat belajar secara maksimal, siswa harus menggunakan keseluruhan 
indrawinya dalam berinteraksi dengan benda konkret di sekitarnya. Anak-anak belajar terbaik melalui indera dominan mereka, yaitu melihat, mendengar dan menyentuh (Wey, Lin, Chen, Application, \& Chen, 2014). Multimedia interaktif dapat melibatkan ketiga indera ini secara bersamaan melalui berbagai representasi visual, suara dan kapasitas untuk menyentuh dan berinteraksi dengan multimedia interaktif.

Selain sesuai dengan perkembangan kognitif siswa, keberhasilan multimedia interaktif yang dikembangkan juga diperngaruhi oleh kemampuan multimedia interaktif untuk meningkatkan rentang perhatian siswa dalam proses belajar. Anak pada usia operasional konkret yaitu 7-11 tahun, rentang perhatian maksimal yang dapat dilakukan memanglah hanya dibawah 15 menit saja. Oleh karena itu, dibutuhkan penggunaan media berfungsi untuk meningkatkan minat dan ketretarikan siswa dalam kegiatan di kelas (Naz \& Akbar, 2010). Multimedia bersisi berbagai media, mulai dari gambar, animasi, video, dan suara yang dapat mendorong siswa untuk memperhatikan lebih lama daripada biasanya. Pernyataan tersebut diidukung penelitian yang dilakukan oleh (Ian Hall \& S Higgins, 2005), bahwa berbagai element dalam multimedia dapat membantu meningkatkan keterlibatan, motivasi dan rentang perhatian siswi dalam proses pembalajaran. Sesuai pula dengan pernyataan (Kirkorian et al., 2008) yang menyatakan bahwa pada masa kanak-kanak, fitur yang menonjol secara mencolok seperti gerakan dan efek suara dapat mendorong perhatian. Multimedia interaktif memiliki semua komponen yang dapat menarik perhatian siswa, mulai dari gambar yang menarik, animasi yang menarik, video yang tidak membosankan, dan interactive link yang seakan-akan memberikan tanggapan pada setiap gerak-gerik siswa.

Multimedia interaktif dapat membuat siswa aktif bergerak dan tidak hanya menjadi pendengar yang pasif. Hal ini tentu memengaruhi keberhasilan pembelajaran. Siswa sekolah dasar tidak bisa diam dalam waktu yang lama. Anak-anak hanya bisa bertahan duduk paling lama adalah 30 menit (Alim, 2009). Multimedia interaktif dapat berhasil dalam pembelajaran karena multimedia interaktif dapat memfasilitasi karakteristik siswa yang suka bergerak dan tidak bisa diam (Sanjaya, 2010). Multimedia interaktif mampu membuat anak terlibat aktif dalam kegiatan belajar melalui kemampuannya memberikan tanggapan dan respon, serta membuat interaksi antar teman dan guru menjadi lebih intens.

Berdasarkan kajian dan pemamparan produk yang telah direvisi, dapat ditarik kesimpulan mengenai kelebihan dari produk multimadia interaktif yang dikembangkan ini adalah antara lain: (1) multimedia interaktif telah dinyatakan layak digunakan sebagai madia pembelajaran dengan memenuhi kriteria kevalidan, kemenarikan, kepraktian, dan kefektifan; (2) Multimadia interaktif dapat menigkatkan hasil belajar; (3) multimadia interaktif dapat digunakan secara individu/mandiri, kelompok, atau klasikal; (4) multimedia interaktif dapat membuat siswa mudah menerima pembelajaran dan tidak cepat bosan. Hal ini dipengaruhi oleh adanya gambar, video, serta animasi yang menarik, (5) multimedia interaktif dapat memberikan umpan balik secara cepat pada siswa, misalnya pada kegiatan menjodohkan atau soal evaluasi.

Berdasarkan pemaparan kevalidan dan keefektifan multimedia interaktif, dapat dinyatakan produk yang dikembangkan telah valid dan berhasil meningkatkan hasil belajar siswa. Namun, masih terdapat berbagai kekurangan-kekurangan yang disadari setelah penerapan multimedia interaktif ini. Adapun kekurangan tersebut, antara lain (1) multimedia interaktif hanyaa dikembangkan pada pembelajaran tematik tema indahya kebesarsamaan subtema kebaragaman budaya bangsaku; (2) multimedia interaktif di dalamnya terdapat suara, baik suara backsound maupun suara dalam video. Di sekolah tidak disediakan headset untuk siswa sehingga sebelum pelaksanaan uji coba sebaiknya setiap siswa diminta membawa headset sendiri; (3) media yang baik adalah media yang dikembangkan sesuai dengan perkembangan zaman (Avianty \& Cipta, 2018), misalnya penggunaan multimedia interaktif yang ternyata cukup efektif untuk meningkatkan tidak hanya keterampilan konsep, melainkan keterampilan berpikir kritis juga (Husein, Herayanti, \& Gunawan, 2017). Adapun media yang sangat dibutuhkan saat ini adalah media yang dapat menunjang pengembangan berpiikir siswa pada taraf berpikir tingkat tinggi. Kemampuan berpikir tingkat tinggi dapat direalisasikan dengan pembalajaran yang berbasis konstruktivistik (Akbar, 2016; Siregar, 2018). Apabila dibandingkan dengan hasil penelitian ini, maka kekurangan multimedia interaktif dalam penelitian ini yaitu, masih belum dapat mengembangkan higher order thingking skill siswa secara maksimal, dikarenakan belum berbasis pembelajaran yang bersifat konstruktivistik. Oleh karena itu, penggunaan multimedia interaktif sebaiknya tidak digunakan sebagai satu-satunya sumber belajar.

Muatan karakter di dalam multimedia interaktif yang dikembangkan terbatas pada karakter toleransi, kerjasama, menghargai, dan menerima keberagaman. Hal ini dikarenakan pengembangan materi disesuaikan dengan tema yang diangkat, yakni indahnya kebarsamaan dengan spesisikasi subtema kebaragaman budaya bangsaku. Disisi lain, multimedia interaktif memiliki potensi besar sebagai salah satu media penanaman nilai-nilai karakter (Syahbrudin, 2018). Apabila dibandingkan penelitian tersebut, maka multimedia interaktif yang dikembangkan dalam penelitian ini masih mengandung sebagian kecil nilai karakter yang diharapkan pemerintah. Oleh karena itu, dalam penerapannya guru dapat menyisipkan nilai-nilai karakter yang tidak ada di dalam multimedia interaktif secara langsung dalam pembelajaran.

\section{SIMPULAN}

Penelitian dan pengembangan yang telah dilakukan menghasilkan produk multimedia interaktif yang valid, praktis, menarik, dan efektif. Hal ini dapat dilihat dari hasil validasi ahli yang mendapatkan persentase mencapai $92,9 \%$ beserta angket pengguna terkait kepraktisan dan kemenarikan mencapai 94,5\% dan 95,9\%. Berdasarkan hasil uji-t diperoleh nilai t-empirik yang lebih besar daripada t-tabel, baik pada ranah kognitif, afektif dan psikomotor sehingga dapat disimpulkan bahwa multimedia interaktif efektif untuk meningkatkan hasil belajar siswa. 
Saran untuk penelitian dan pengembangan lebih lanjut (1) multimedia interaktif hanya terbatas pada pembelajaran tema 1 di kelas IV, yakni indahnya kebesarsamaan subtema kebaragaman badaya bangsaku sehingga perlu dikembangkan materi pada tema-tema lain sehingga dapat dijadikan sebagai alternatif media pembelajaran oleh guru; (2) pengembangan produk selanjutnya harus dikemas lebih menarik dan lebih kreatif serta bervariasi misalnya dengan penambahan game di dalam multimedia interaktif; (3) pengembangan produk selanjutnya harus berbasis pembelajaran; (4) konstruktivistik sehingga mampu mengasah dan mengembangkan kemampuan berpikir tingkat tinggi pada siswa; (5) pengembangan multimedia interaktif diharapkan dapat bermuatan karakter yang lebih kompleks supaya dapat mengembangkan ranah sikap siswa secara lebih baik.

\section{DAFTAR RUJUKAN}

Akbar, T. N. (2016). Pengembangan Multimedia Interaktif IPA Berorientasi Guided Inquiry pada Materi Sistem Pernapasan Manusia Kelas V SDN Kebonsari 3 Malang. Jurnal Pendidikan: Teori, Penelitian, dan Pengembangan, 1(6), 1120-1126.

Alwi, S. (2017). Problematika Guru Dalam Pengembangan. Itqan: Jurnal Ilmu-Ilmun Kependidikan, 8(2), $145-167$.

Arkün, S., \& Akkoyunlu, B. (2008). A Study on The Development Process of a Multimedia Learning Environment According to the ADDIE Model and Students' Opinions of the Multimedia Learning Environment. Digital Education Review, 17(17), $1-19$.

Avianty, D., \& Cipta, D. A. S. (2018). Pengembangan Multimedia Interaktif Berbasis Masalah Untuk Mendayagunakan Kemampuan Berpikir Tingkat Tinggi Pada Siswa Sekolah Dasar. AKSIOMA: Jurnal Program Studi Pendidikan Matematika, 7(2), 237. https://doi.org/10.24127/ajpm.v7i2.1503

Bradbury, N. A. (2016). Attention Span During Lectures: 8 Seconds, 10 Minutes, or More? Advances in Physiology Education, 40(4), 509-513. https://doi.org/10.1152/advan.00109.2016

Carlson, J. A., Engelberg, J. K., Cain, K. L., Conway, T. L., Mignano, A. M., Bonilla, E. A., ... Sallis, J. F. (2015). Implementing Classroom Physical Activity Breaks: Associations with Student Physical Activity and Classroom Behavior. Preventive Medicine, 81, 67-72. https://doi.org/10.1016/j.ypmed.2015.08.006

Fui-Theng LEOW, \& Assoc. Prof. Dr Mai NEO. (2014). Interactive Multimedia Learning: Innovating Classroom Education in a Malaysian University. Turkish Online Journal of Educational Technology, 13(2), 99-110.

Gunawardhana, P. D., \& Palaniappan, S. (2016). Using Multimedia as an Education Tool. International Conference on Computer Games Multimedia \& Allied Technologies, 5(1), 98-101. https://doi.org/10.5176/2251-3043

Harsiwi, N., Yuliati, L., \& Suardana, I. M. (2017). Transformasi Pendidikan Abad 21 untuk mengembangkan Pendidikan Dasar Bermutu dan Berkarakter. Bahan Ajar Kontekstual Subtema Keindahan Alam Negeriku untuk Siswa Sekolah Dasar, 861868.

Husein, S., Herayanti, L., \& Gunawan, G. (2017). Pengaruh Penggunaan Multimedia Interaktif terhadap Penguasaan Konsep dan Keterampilan Berpikir Kritis Siswa pada Materi Suhu dan Kalor. Jurnal Pendidikan Fisika dan Teknologi, 1 (3), 221. https://doi.org/10.29303/jpft.v1i3.262

Ian Hall, \& S Higgins. (2005). Primary School Students' Perceptions of Interactive Whiteboards. Journal of Computer Assisted Learning, 21(2), 102-117. http://dx.doi.org/10.1111/j.1365-2729.2005.00118.x

Ilhan, G. O., \& Oruç, S. (2016). Effect of the use of multimedia on students' performance: A case study of social studies class. Educational Research and Reviews, 11(8), 877-882. https://doi.org/10.5897/ERR2016.2741

Kirkorian, H. L., Wartella, E. A., \& Anderson, D. R. (2008). Media and Young Children's Learning. Future of Children, 18(1), 39-61. https://doi.org/10.1353/foc.0.0002

Komba, S. C., \& David, N. (2015). The Use of Computers by Primary School Pupils in Morogoro, Tanzania. International Journal of Research Studies in Educational Technology, 5(1). https://doi.org/10.5861/ijrset.2016.1431

Kurniawan, M. P. (2018). Perancangan Media Pembelajaran Untuk Anak Usia Dini "Mengenal Nama-Nama Benda". SEMNASTEKNOMEDIA ONLINE, 6(1), 25-30.

Levin, E., \& Bernier, J. (2011). Encyclopedia of Child Behavior and Development. In Encyclopedia of Child Behavior and Development. https://doi.org/10.1007/978-0-387-79061-9

Manjale, N. B., \& Abel, C. (2017). Significance and Adequacy of Instructional Media as Perceived by Primary School Pupils and Teachers in Kinondoni District, Tanzania. International Journal of Educational Policy Research and Review, 4(6), 151-157. https://doi.org/10.15739/IJEPRR.17.016

Mayer, R. E. (2003). The Promise of Multimedia Learning: Using the Same Instructional Design Methods Across Different Media. Learning and Instruction, 13(2), 125-139. https://doi.org/10.1016/s0959-4752(02)00016-6

Mikre, F. (2011). The Roles of Information Communication Technologies in Education. Ethiopian Journal of Education and Sciences, 6(2), 109-126.

Naz, A. A., \& Akbar, R. A. (2010). Use of Media for Effective Instruction its Importance : Some Consideration. Journal of Elementary Education, 18(1-2), 35-40.

Ngussa, B. M., \& Chiza, A. (2017). The Influence of Instructional Media Use on Pupils' Mastery of Reading and Writing in Kiswahili Language in. International Journal of Educational Policy Research and Review, 4(8), $187-194$.

Nilasari, E., Adrian, Y., \& Susanto, R. (2018). Pembelajaran Tematik Berbasis Kontekstual di SD Muhammadiyah 9 Malang. Jurnal Teori dan Praksis Pembelajaran IPS, 3(1), 19-26. https://doi.org/10.17977/um022v3i12018p019 
Nusir, S., Alsmadi, I., Al-Kabi, M., \& Shardqah, F. (2011). Designing an Interactive Multimedia Learning System for the Children of Primary Schools in Jordan. 2011 IEEE Global Engineering Education Conference, EDUCON 2011, (May 2014), 45-51. https://doi.org/10.1109/EDUCON.2011.5773111

Osman, K., \& Lee, T. T. (2014). Impact of Interactive Multimedia Module With Pedagogical Agents on Students' Understanding and Motivation in the Learning of Electrochemistry. International Journal of Science and Mathematics Education, 12(2), 395-421. https://doi.org/10.1007/s10763-013-9407-y

Prasetya, A. Y. W. N., Kuswandi, D., \& Akbar, S. (2018). Multimedia Interaktif pada Pembelajaran Tematik untuk Kelas IV Sekolah Dasar. Jurnal Pendidikan: Teori, Penelitian, dan Pengembangan, 3(11), 1423-1427.

Serva, M. A., \& Fuller, M. A. (2004). Aligning What We Do and What We Measure in Business Schools: Incorporating Active Learning and Effective Media Use in the Assessment of Instruction. Journal of Management Education, 28(1), 19-38. https://doi.org/10.1177/1052562903252648

Siagian, R. E. F. (2015). Pengaruh Minat dan Kebiasaan Belajar Siswa terhadap Prestasi Belajar Matematika. Formatif: Jurnal Ilmiah Pendidikan MIPA, 2(2), 122-131. https://doi.org/10.30998/formatif.v2i2.93

Siregar, A. M. (2018). Efektivitas Pendekatan Konstruktivisme Terhadap Kemampuan Pemecahan Masalah Matematis Siswa Di Smp Negeri 5 Sipirok. JURNAL MathEdu (Mathematic Education Journal), 1(3), 1-10.

Syahbrudin, J. (2018). Multimedia Interaktif Berbasis Karakter sebagai upaya Peningkatan Nilai-Nilai Karakter dan Kemampuan Berpikir Tingkat Tinggi. Computer Engineering, Science and System Journal, 3(1), 7. https://doi.org/10.24114/cess.v3i1.8322

Wamalwa, E. J., \& Wamalwa, W. (2014). Towards the Utilization of Instructional Media for Effective Teaching and Learning of English in Kenya. Journal of Education and Practice, 5(31), 2222.

Wey, S., Lin, Y., Chen, S., Application, S. C., \& Chen, S. (2014). Application of Interactive Whiteboard on Remedial Instruction for EFL Low Achievers. International Journal of Contemporary Educational Research, 1(1), 34-41-41.

Zuriah, N., Sunaryo, H., \& Yusuf, N. (2016). IbM Guru Dalam Pengembangan Bahan Ajar Kreatif Inovatif Berbasis Potensi Lokal. Jurnal Dedikasi, 13, 39-49. 